\title{
Identification of Land Use Coverage through Ground Check GPS Data (Case Study in Tapaktuan District)
}

\author{
Safridatul ‘Audah".1.* Mislina, Afdhal, Muharratul Mina Rizky \\ ${ }^{a}$ Departermet of Industrial Engineering, Politeknik of Aceh Selatan, \\ Department of Informatics Engineering, Politeknik of Aceh Selatan, \\ ${ }^{a}$ Departermet of Industrial Engineering, Universitas Syiah Kuala, Banda Aceh,Indonesia \\ Department of Electrical Enginering, Universitas Syiah Kuala, Banda Aceh,Indonesia \\ Komplek Reklamasi Pantai. JL. Mardeka, Tapaktuan, Indonesia \\ ${ }^{1}$ E-mail: Safridatul@yahoo.co.id* \\ * corresponding author
}

Tapaktuan is a region of the west coast of Aceh which has high forest and biodiversity potential in Indonesia because most of this region is part of the Leuser Ecosystem which is known to have high biodiversity and needs to be preserved. land conversion is a big challenge for this region because of development and development activities as well as population growth. The purpose of this study is to identify land use using GPS devices. The method is by first grounding the field with GPS MAPS GARMIN type 60 CSx then the data is stored on the device. Next determine the position of the object points and then input using Mapsource software to be processed into

Keywords:

Tapaktuan

Land Use

GPS ArcGIS. to obtain information in the field in the form of observations of land cover in the field and the coordinates. Based on the results of groundchek observations in the field as many as 299 points obtained 7 types of land cover in the field consisting of bodies of water, forests, plantations, dryland agriculture, vacant land, settlements, and shrubs. The coordinates were taken covering 15 villages in the Tapaktuan sub-district, South Aceh Regency.

Copyright (C) 2020 Politeknik Aceh Selatan. All rights reserved.

\section{Introduction}

Tapaktuan is the west coast region of Aceh and is the administrative center of South Aceh Regency known as Naga City. Tapaktuan is an area that has high forest potential and biodiversity in Indonesia because most of this area is part of the Leuser Ecosystem which is known to have high biodiversity and needs to be preserved. The cause of land conversions from agricultural land to settlements as well as from forest land to estate crops and agriculture is the development and development activities in Tapaktuan are a big challenge for this region. This happens because the population is increasing, the need for land to be used as settlements, agricultural land, plantation is very necessary. Monitoring and evaluation of land cover needs to be carried out at certain periods for planning, managing and monitoring environmental changes. In urban areas, changes generally have a relatively similar pattern, namely the change of other land uses into urban land [3].

Land capability places more emphasis on the capacity of various land uses in general that can be cultivated in an area. Land capability is a physical environment that includes climate, relief, soil, hydrology, and vegetation. These factors to some extent affect the potential and ability of land to support a particular type of use [5]. Sensory applications can be applied together with Geographic Information Systems (GIS) for research in mapping land use, namely in terms of 
measurement, mapping and monitoring so as to produce good enough information, as well as efficient both in terms of time and cost and make it easier to plan and make decisions [6].

The use of technology is increasingly advanced and rapid, which is marked by the development of measurement tools, especially in the field of mapping and positioning at a point on the surface of the earth such as remote sensing technology tools to find out land cover and this research has also been conducted [1-2] [7]. In addition to remote sensing technology, a GPS (Global Positioning System) tool that can be used for mapping land use by determining the position of objects. The purpose of this study is to identify land use through GPS GPS data to obtain information in the field in the form of observations of land cover in the field and the coordinates. Global Positioning System (GPS) is a satellite-based navigation system that provides information about locations on the surface of the earth. GPS systems use geometric measurements of four or more satellite signal catches to the instrument used [4].

\section{Method}

This research was conducted in the area of South Aceh Regency located at $02^{0} 23$ '24 "- $03^{0}$ 44' 24" LU and $96^{\circ} 57^{\prime} 36^{\prime \prime}$ "- 97 56' 24" East, especially in Tapaktuan by conducting a field survey using equipment Global Positioning System (GPS) MAPS GARMIN type 60 CSx to make a map of the location of land use in the area. Because GPS is a tool that is able to map direct observation points when measuring land cover locations with coordinates that are exactly the same as pictures, so it can make a geographic information system to determine land use. The stages carried out in this study are

1. Conduct a ground check first in the field then with GPS MAPS GARMIN type 60 CSx then the storage of data is stored in the device.

2. The position of the object points is presented as the original appearance on the GPS GARMIN 60Csx receiver which is then inputted using Map source software to be processed into ArcGIS.

3. Data These GPS points will be changed into segments / segments of the object's representation line by connecting each pair of points with an arc that is specific to each type of object, then labeled according to their identity.

4. Measurement of position points in the field as a whole has represented a picture of the situation of the research location. Every person who is given the Forest code (f01, f02, ..., f0n), Settlement (S01, S02 ... Sn) identity (with numbers or letters), or a combination has information in the form of position information with a Geographic projection system, and datum based on WGS 1984 Because not all points / codes are landmarks that are easily recognizable at the location, only codes that represent landmarks are displayed.

\section{Results and Discussion}

The characteristics of land cover in Tapaktuan can be seen visually which dominates the area according to observations. Observations in this study were made subjectively based on the conditions in the field. Field observations are made with the aim of adjusting the state of land cover. In this study, observations were made using a GPS (Global Positioning System) by conducting a ground check to obtain information in the field containing observations of land cover in the field and coordination points. Based on the observation groundchek as many as 299 points obtained 7 types of land cover in the field consisting of bodies of water, forests, plantations, dryland agriculture, open land (vacant land), settlements, and shrubs. The coordinates were taken covering 15 villages in the Tapaktuan sub-district, South Aceh Regency. Following the results of documentation of field observations obtained characteristics of land cover in Tapaktuan as in Table. 1 
Table 1. Land Use in Tapaktuan

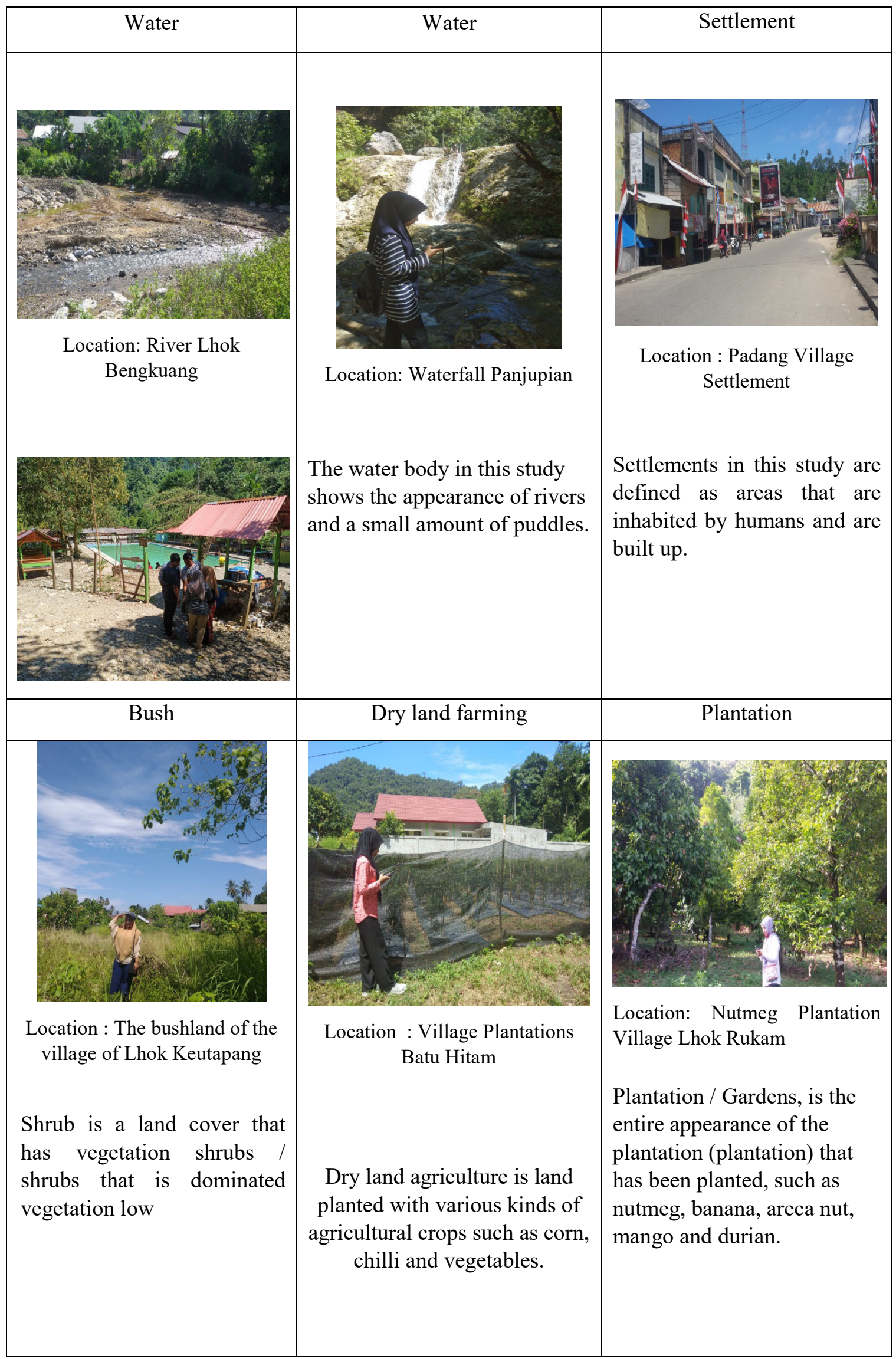




\begin{tabular}{|l|l|l|}
\hline \multicolumn{1}{|c|}{ Forest } & \multicolumn{2}{|c|}{ Open land } \\
\hline & & \\
\hline $\begin{array}{l}\text { Location : Forest Panton luas } \\
\text { The forest in this study is a } \\
\text { land cover with mixed } \\
\text { vegetation types with natural } \\
\text { characteristics or overgrown } \\
\text { with forestry plants or teak } \\
\text { forest vegetation }\end{array}$ & $\begin{array}{l}\text { Location : Park Pala Tapaktuan } \\
\text { forms and patterns that spread } \\
\text { between settlements, roads and }\end{array}$ & $\begin{array}{l}\text { Open land is an area in the } \\
\text { form of vacant land that is } \\
\text { not overgrown by any } \\
\text { vegetation. }\end{array}$ \\
\hline
\end{tabular}

The results of groundcheck distribution points in the field are then mapped using ArcGIS can be seen in Figure 1. In order to obtain information on the position of the land cover point. Such information can be used for further research which is used as a check on the truth of the results of visual classification which results can be used as an example area (training area) in the classification of digital images such as landsat images or other satellite images. 


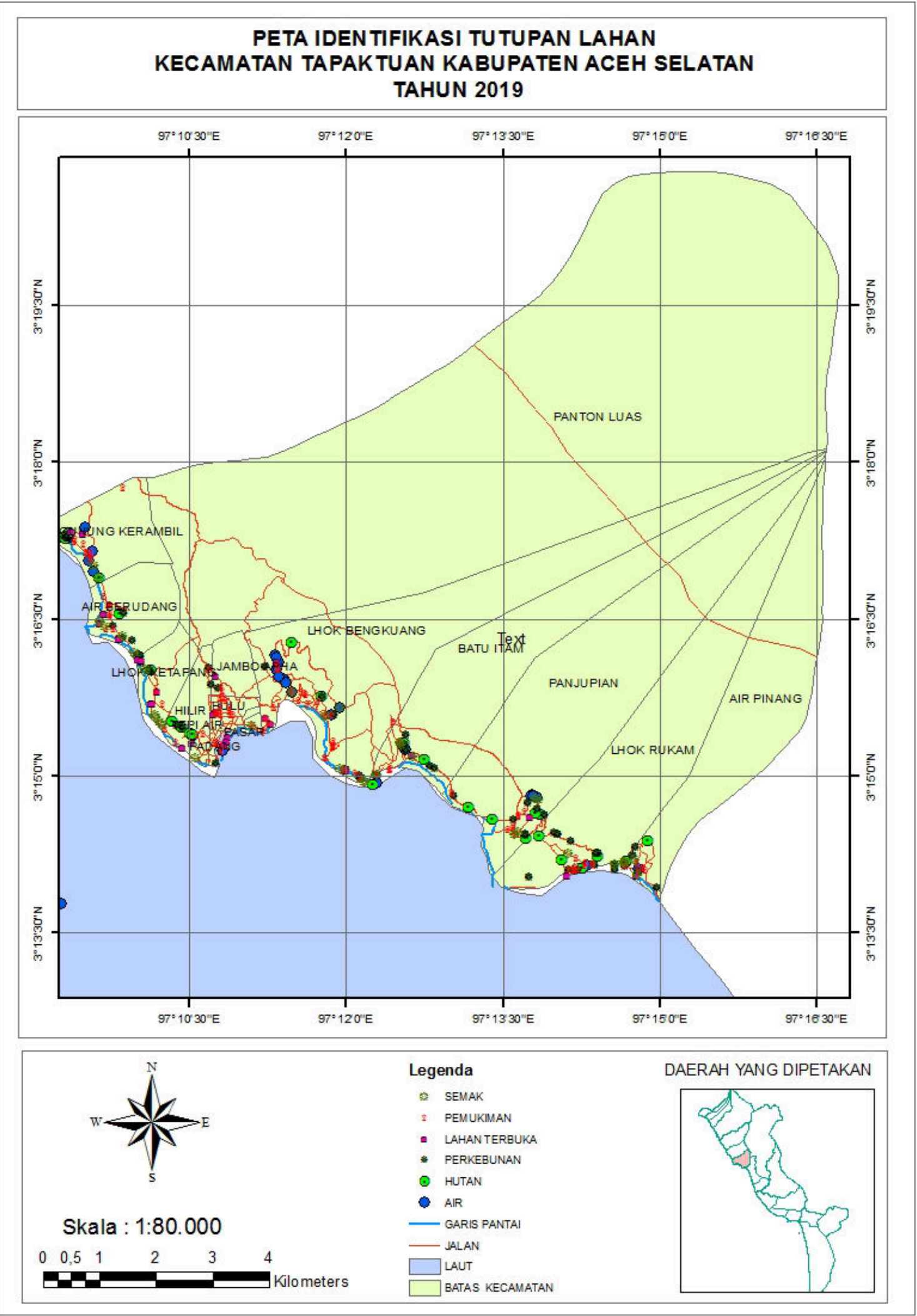

Figure 1. Map of the ground cover check point for land in 2019 


\section{Conclusion}

The conclusion from the results of this study is the investigation of land cover in South Aceh District. Special District Tapaktuan can be done using GPS devices. Based on field observations, the characteristics of the land obtained in the area consist of bodies of water such as rivers, waterfalls and ponds. Housing that is marked by buildings such as office buildings, shop houses in residential areas and residential residents. Dry land agriculture is land that is planted with a variety of agricultural crops such as corn, chili and vegetables. Nutmeg plantations, bushes, protected forests and open areas.

\section{Acknowledgment}

On this occasion the authors would like to thank the Kemenristek Diktik for funding the completion of the Beginner Lecturer Research (PDP) in 2019 and a thank you also extended to the South Aceh Polytechnic Industrial Engineering Study Program for providing space and time for research.

\section{References}

[1] 'Audah, S., Nazliyati., Utilization of Satellite Landsat-8 Operational Land Imager (OLI) for Land Cover Classification Nutmeg Plantation In Tapaktuan Sub-District. Jurnal Inovasi Teknologi dan Rekayasa. Vol 3. No. 1 : PP. 23 -28., Juni 2018.

[2] 'Audah, S., et all., Visual Analysis of Satellite Landsat Images Multitemporal and GPS as a Geographic Information System for Mapping of Nugmet Plantations in Tapaktuan., IOP Conference Series: Materials Science and Engineering., doi:10.1088/1757-899X/506/1/012037.

[3] Hartono, dkk., Analisis Citra Multitemporal untuk kajian perubahan penggunaan lahan di kota Surabaya, kabupaten Gresik dan Sidoarjo tahun 1994-2012, Laporan Penelitian, Fakultas Geografi, Universitas Gadjah Mada, Yogyakarta. 2012.

[4] Musnanda, S., Pengunaan GPS Dalam Pengambilan Data Spatial untuk Perencanaan Ruang., posted on June 6, 2012. https://musnanda.com/2012/06/06/pengunaan-gps-dalam-pengambilan-data-spatial-untukperencanaan-ruang/

[5] Sitohang, J. L., Sitorus, S., \& Sembiring, M. Evaluasi Kemampuan Lahan Desa Sihiong, Sinar Sabungan dan Lumbun Lobu Kabupaten Toba Samosir. Agroekoteknologi, 1(3).., 2013.

[6] Susianti, H., \& Habib. S., Aplikasi Penginderaan Jauh Dalam Pemetaan Penggunaan Lahan Detil Tapak RDE, PUSPIPTEk Serpong., Vol. 18., No. 2 : PP. 101-102., 2016.

[7] Vanjare. A., et all., Satellite Image Processing for Land Use and Land Cover Mapping., International Journal Image Graphics and Signal Processing, 10, PP. 18-28., 2014. DOI: 10.5815/ijigsp.2014.10.03 